\title{
Lirasniara, the sung language of Southwest Maluku (East-Indonesia)
}

\author{
AONE VAN ENGELENHOVEN
}

\begin{abstract}
This paper discusses a highly endangered sung style in Maluku Barat Daya along the lines of Sasse's (1992) theory of language death and focusses on structural consequences, the speech behaviour, and the external setting of this oral tradition. It is concluded that if it really has existed and not only in local folklore, Lirasniara must have been a jargon that was replaced by Malay. Only because it already occurred in sung texts during the latter's introduction prevented its total disappearance from the region thus far. The fear remains that in the process of the modernization of Indonesia, it may undoubtedly disappear after all in the near future.
\end{abstract}

KEYWORDS

Singing, argot, jargon, Southwest Maluku, trade language.

\section{INTRODUCTION}

Southwest Maluku (East-Indonesia) is a small region that is both linguistically and culturally complex. The Austronesian isolects spoken in this area have been identified as members of a single Southwest Malukan Group (Taber 1993). The isolects of Kisar, Roma, and the dialect chain extending from Leti up to Tepa on West-Babar are considered descendants of a single protolanguage, called Proto Luangic-Kisaric (henceforth PLK, Van Engelenhoven 1995). Based on Taber's (1993) lexicostatistical findings, the Wulur language on East-Damar may well be another descendant of PLK. ${ }^{1}$ The languages of

1 Both East-Damarese (= Wulur) and the Kisar-Roma Subgroup have a shared lexicon

AONE VAN ENGELENHOVEN is assistant professor in Southeast Asian Linguistics at the Leiden University Centre for Linguistics (LUCL) and the School of Asian Studies at the Leiden Institute of Area Studies (LIAS), both at Leiden University, the Netherlands. His main research interests are descriptive linguistics, sociolinguistics, and oral tradition in East Indonesia, East Timor, and the Malukan community in the Netherlands. His recent publication is "The position of Makuva among Austronesian languages of East Timor and Southwest Maluku", in K. Alexander Adelaar and Andrew Pawley (eds), Austronesian historical linguistics and culture history; A festschrift for Bob Blust, pp. 424-441 (2009, Canberra: Pacific Linguistics). Aone van Engelenhoven may be contacted at: a.van.engelenhoven@hum.leidenuniv.nl.

(C) 2010 Faculty of Humanities, University of Indonesia 
Wetar and Babar cluster into separate subgroups of the same Southwest Malukan Group. The Amaya language of West-Damar and Oirata of SouthKisar are an Austronesian and non-Austronesian isolate respectively. This paper focuses on the speech communities in the districts of Damer (Damar Island), Pulau-pulau Terselatan (Kisar and Roma Islands), ${ }^{2}$ Serwaru (Leti Island), Moa-Lakor (Moa and Lakor Islands), Mdona-Hiera (Luang and Sermata Islands), and Pulau-pulau Babar (Wetan and Babar Island) ${ }^{3}$. Each speech community in this region distinguishes two speech styles beside informal lirlèta "village-talk":4 a) secret languages, for example lirmetrialma "inside-reef-talk" on Luang, and b) literary languages, for example lirmarna "marna-talk", which features extensive lexical parallelism. As far as we know now, the diverse languages in the area tend to share most lexical pairs (Van Engelenhoven 1997). This paper focuses on one special literary language, the so-called lirasniara (henceforth LS) or "song-talk". This speech style is said to be used over the island range extending from Tepa (West-Babar) in the East up to Kisar in the West. Its most spectacular and suspect feature is the fact, that it must be sung, as already implied by its name.

Whereas all speech communities will stress the uniqueness of the own dialect or language compared to others, it is a generally accepted idea, that LS is virtually the same in the Wonreli, Serwaru, and Tepa Districts. Therefore, speakers of different dialects and mutually unintelligible languages are said to understand each other while singing. However, due to all kinds of extra linguistic phenomena during and after the Indonesian Independence, knowledge of LS has not been transmitted to the younger generations and is expected to be extinct within the next 20 years.

Following Sasse (1992: 9-10) three types of phenomena are discussed that are related to the death of LS: Structural consequences (Paragraph 2), concerning "the purely structural, substantial-linguistic set of phenomena, for example, changes in phonology, morphology and lexicon [...]", Speech behaviour (Paragraph 3), concerning "the regular use of variables in a given speech community, which are bound by social parameters [...]", and the External setting (Paragraph 4), concerning "the entire range of extra linguistic factors leading to language death, for example, cultural, sociological, ethnohistorical processes". The findings are discussed in Paragraph 5.

\section{STRUCTURAL CONSEQUENCES}

\subsection{SOUND CHANGES}

The following sound changes are attested in LS:

with the Luang language (= Luangic) of 55\% (Taber 1993).

2 Generally referred to as Wonreli District.

Generally referred to as Tepa District.

4 "village" does not fully encompass the meaning of lèta (Van Engelenhoven 2004). In this paper Leti terminology will be used unless specifically stated differently. 
1a PLK *u(C)a > LS o(C)a: PLK *ua "fruit" > LS: woa, Meher: ?, Leti: vua-, Moa, Wetan: voa-, PLK *ruma "house" > LS: rome, Meher, Moa, Wetan: roma, Leti: ruma

b PLK *u\# > LSi\#: PLK *vatu "stone"> LS: wakie, Meher waku, Leti, Moa vatu, Wetan: wati; PLK *vunu "God" > LS: wunie, Meher wunu, Leti, Moa: vunu, Wetan: vuni; PLK *polu "call" > LS: polie "call", Meher, Leti, Moa: polu, Wetan: poli

c $\quad$ PLK *u > LS i / _ Ci\#: PLK *ka(q)ulu "shout" > LS: kailie, Meher: wakau, Leti: ka:lu, Moa: kaglu, Wetan: kaili, PLK *pupunu "shut" > LS: pupini, Meher: ?, Leti, Moa: pupnu, Wetan: pupna

d PLK \#uV > LS \#yV: PLK *uairi "water" > LS: yoirie, Meher: oiri, Leti: uera, Moa: gera, Wetan: yera

2 PLK *_s_> LS h: PLK *masa "gold", LS: mahe "gold", Meher, Moa: maha, Leti: masa, Wetan: maa; PLK *resi "win" > LS: rehie, Meher, Moa: rehi, Leti: resi, Wetan: rei; PLK *mesi "ugly" > LS, Meher, Moa: mehi, Leti: mesi, Wetan: mei

3 PLK *t > LS k: PLK *tutu "point", LS: kukie, Meher: kuku, Leti, Moa: tutu, Wetan: tuti, PLK *talan "road" > LS: kalana, Meher: kalla, Leti, Moa, Wetan: talla, PLK *mata "eye" > LS: make, Meher: maka-, Leti, Moa, Wetan: mata

$4 \quad$ PLK * $\mathrm{q}^{5}>$ LS $\varnothing$ : PLK *anaq "child"> LS: ane, Meher: tatana, Leti: a:na-, Moa: an'a, Wetan: aana, PLK *vuqar "mountain" > LS: wura, Meher: wo'oro, Leti: vu:ra, Moa: vo'ora, Wetan: wo’ora, PLK *teqa "arrive" > LS: ke, Meher, Wetan: ?, Leti: tea, Moa: te'a

5 PLK *\#C(V)C > LS C: PLK *mak(a)lekane "rude" > LS: lekana, Meher: ?, Leti, Moa, Wetan: maklekna, PLK *s(a)rui "garfish" > LS: ruie, Meher: ?, Leti: srui, Moa: hrui, Wetan: rui, PLK *k(i)deli "ring" > LS: delie, Meher ideli, Leti, Moa, Wetan: kdieli

Interestingly, LS features sound changes that are characteristic for separate subgroups in Luangic-Kisaric. All East-Luangic isolects feature the lowering of the back high vowel in penultimate position before final *a (rule 1a), while fronting of the back high vowel in final position (rule 1b) is a feature of WetanTepa. The loss of the glottal stop (rule 4) is an exclusive innovation of Leti and the change of *t to / k/ (rule 3) is confined to Kisaric Meher. On first sight these sound changes seem to indicate, that LS be a first order branch next to Proto-Luangic and Proto-Kisaric. LS differs from Luangic in that it lacks any consonant cluster, and from Kisaric in that it only has open syllables.

\subsection{GRAMMAR}

Verbs can be inflected for person and number through prefixation, as in all Luangic-Kisaric languages. This is exemplified by the verb walie "to (re)turn":

$\begin{array}{llll}1 \mathrm{sg} & \text { ai wialie } & 1 \mathrm{pl} & \text { ka-walie } \\ 2 \mathrm{sg} & \text { mo-walie } & 2 \mathrm{pl} & \text { mo-walie } \\ 3 \mathrm{sg} & \text { na-walie } & 3 \mathrm{pl} & \text { ra-walie }\end{array}$

In the following table below the set of LS person inflections is compared with the (full form) sets in the area languages: respectively. 


$\begin{array}{cllllll}\text { Meh. } & \text { Jer. } & \text { Leti } & \text { Moa } & \text { Wet. } & \text { LS } & \text { GLOSS } \\ { }^{-} & u- & u- & g o- & (a) i- & (a) i & 1 \mathrm{sg} \\ m- & m- & m u- & m o- & m i- & m o- & 2 \mathrm{sg} \\ n- & n a- & n a- & n a- & n a- & n a- & 3 \mathrm{sg} \\ k- & t a- & t a- & t a- & t a- & k a- & 1 \mathrm{plinc} \\ m- & m a- & m a- & m a- & m a- & k a- & 1 \mathrm{plex} \\ m- & m i- & m i- & m i- & m i- & m o- & 2 \mathrm{pl} \\ r- & r a- & r a- & r a- & r a- & r a- & 3 \mathrm{pl}\end{array}$

LS and Wetan feature the same 1sg prefix. Similarly, they do not distinguish plural from singular in second person. The second person prefix in LS and the 2sg prefix in Moa are formally alike. Unlike the other Luangic-Kisaric languages, LS lacks an inclusive-exclusive distinction in first person plural.

However, person inflection in LS is becoming obsolete, as in the following example where -kuinie "to fall" is optionally inflected for 3sg (1a) or not (b):

Lera la na-kuinie
sun go 3 sg-fall
"The sun sets ..."

(1b) Lera la kuinie

sun go fall

"The sun sets ..."

In other instances, as with the verb -wera "to separate", the inflections found actually do not fit, as in in (2a) where 1plural instead of 3sg is inflected, as in $(2 b)$ :

$\begin{array}{llllll}\text { Wunie } & \text { ka-wera } \quad \text { lima } & \text { ri } & \text { n-ora } & \text { yalie. } \\ \text { Pleiads } & \text { 1pl-separate } & \text { hand } & \text { man } & \text { 3sg-with } & \text { brother } \\ \text { "God separates man from his brother." } & & \end{array}$

$\begin{array}{lllll}\text { Wunie nia-wera lima ri } & \text { n-ora } & \text { yalie. } \\ \text { Pleiads } & \text { 3sg-separate hand man } & \text { 3sg-with } & \text { brother } \\ \text { "God separates man from his brother." } & & \end{array}$

A verb like-nera, actually meaning "to drift" has only been attested with second person inflection, monera, in LS where it can mean either (3a) "drifting, adrift", (3b) "different, several", or (3c) "to leave" or "to abandon":

(3a) Tewi nia-walinie nui wiaki piali monera lo liwi enie liaie. sugarcane 3sg-bow like stone float 2sg.drift at reef sand beach "Sugarcane bends like driftwood (that) drifts on reefs and shores." 
AONE VAN ENGELENHOVEN, Lirasniara, the sung language of Southwest Maluku147

$\begin{array}{llll}\text { (3b) Suri kiarie roma lulie } & \text { monera. } \\ \text { flow leave house holy } & \text { 2sg.drift } \\ \text { "You leave the different holy homes." (= You marry) }\end{array}$

(3c) Kawa rerie nara lilie iana mo-nera.

stop CONT sister beloved VET 2sg-drift

"Stop, brothers and sisters, do not go away."

A prominent phenomenon in LS texts from the Serwaru and Tepa Districts is the palatalization of initial consonants in the context i\#_V. As in Tewi niawalinie (< tewi nawalinie) and nui wiaki pialie (< nui waki(e) palie) in example (3a). For the time being this is analysed as a kind of liaison that is connected with the metathesis phenomenon of the Luangic isolects. However, palatalization in LS seems to be driven on purely rhythmic grounds rather than grammar as in certain isolects like Tutukeian Leti (Van Engelenhoven 2004).

The syntactic structure of LS parallels in great outline the patterns found in all the Luangic-Kisaric isolects, albeit reducedly. Word order is SV (Subject-Verb), as shown in the examples above. Although forms like rai amane "continent's father" and yalikie "brother" respectively suggest a possessive suffix $n e$ and $k i(e)<k u$ "1sg" (following rule $1 \mathrm{~b}$, which fronts final high vowels, see 2.1), informants generally rejected this idea and considered amane and yalikie as mere "classic" synonyms of ame "father" and yalie "brother". Although the suffix $m u$ has been attested for second person possession, it has not become clear whether this is a loan insertion (see 2.3) or a genuine LS affix. In general the word moi "all" (< Leti: mou, Wetan: momioi) is used to indicate second person. A sentence like (4) therefore has two interpretations:

$$
\begin{aligned}
& \text { La mo-winiote roma salona moie. } \\
& \text { go 2sg-contain house holy all } \\
& \text { (a) "You go and live in all holy houses." } \\
& \text { (b) "You go and live in your holy house." }
\end{aligned}
$$

\subsection{LEXICON}

The field work underlying the present analysis suggests, that LS has a fairly limited lexicon of about 150 items or so. A significant part of the lexicon contains homonyms that are created by the sound changes mentioned under 2.1 above. See the following examples where the reconstructed PLK form is added in parentheses after the glosses:

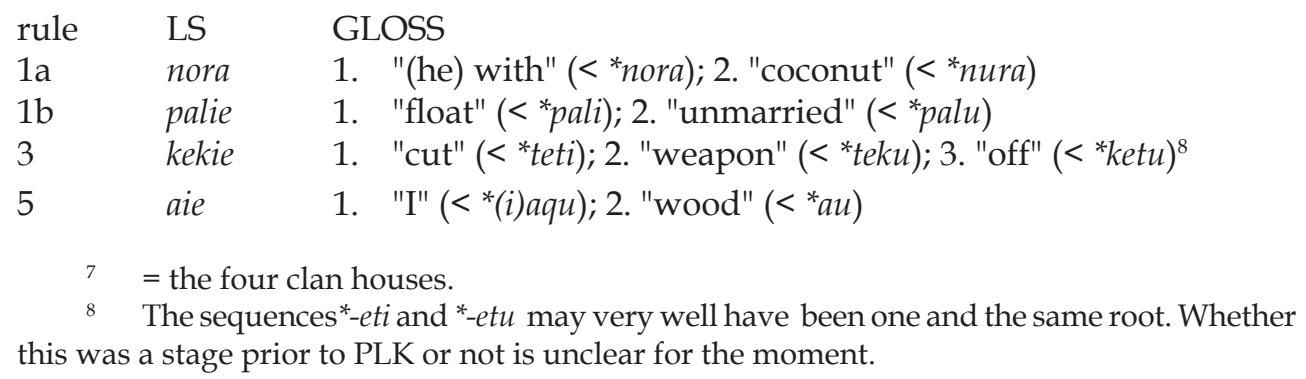

8 The sequences*-eti and ${ }^{*}$-etu may very well have been one and the same root. Whether this was a stage prior to PLK or not is unclear for the moment. 
Homonymy is further increased by the optional realization of penultimate $\mathrm{lu} / \mathrm{as} / \mathrm{o} /$ and the optional deletion of intervocalic $/ \mathrm{h} /$ :

$\begin{array}{llll}\text { GLOSS } & \text { item } & \text { optionally } & \text { homonymous with } \\ \text { "mountain" } & \text { wura } & \text { wora } & \text { "silver" } \\ \text { "tear/sad" } & \text { luie } & \text { loie } & \text { 1. "path"; } 2 . \text { "proa"; 3. "insufficient" } \\ \text { "win" } & \text { rehie } & \text { reie } & \text { "pull" } \\ \text { "ugly" } & \text { mehie } & \text { meie } & \text { "where/wherever" } \\ \text { "oar" } & \text { wehie } & \text { weie } & \text { "wait" }\end{array}$

To obviate the predictable ambiguity that would emerge in the discourse, performers strongly tend to insert words in their speech that originate either from local vernaculars or from Malay. In the following examples loans are printed in upper case. The original form is placed directly under its gloss (underlined).

$\begin{array}{lll}\text { SKARANA } & \text { PETAI } & \text { lime. } \\ \text { sekarang (Mal.) } & \text { patai (Mal.) } & \text { hand } \\ \text { now } & \text { part } & \text { hand }\end{array}$

"Now we do part."

In stead of:

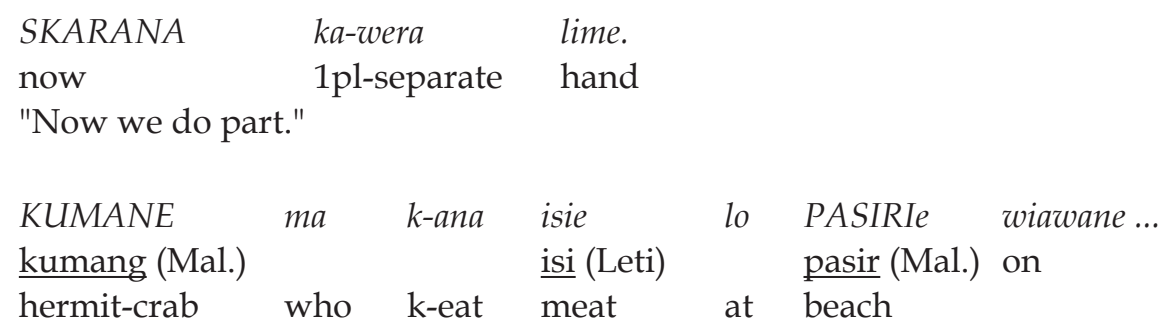

In stead of:

Omale ma k-ana ihie lo eni liai wiawane ...
hermit-crab who k-eat meat at sand beach on
"Hermit-Crab, who eats the meat on the sand ..."

Notice the form pasirie, which contains an added /e/ in analogy with i\# stems, for example wakie "stone", luie "tear" and alike. In the following sentence, which has been taken from a prayer, the verb is inflected with a prefix from daily speech (lirlèta) and the Malay word piara "to guard" is used in stead of the LS combination -riwa rerie:

9 This is probably a loan from Ambonese Malay where it is attested as well (Don van Minde, personal communication). It is unknown, however, in Standard Indonesian. 
AONE VAN ENGELENHOVEN, Lirasniara, the sung language of Southwest Maluku149

(7a)

$\begin{array}{lcclc}\text { T-waka } & \text { rerie } & \text { Isa } & \begin{array}{l}\text { PIARA } \\ \text { piara (Mal.) }\end{array} & \text { molane. } \\ \text { 1plinc-ask } & \text { CONT } & \text { Jesus } & \begin{array}{l}\text { guard } \\ \text { complete }\end{array} \\ \text { "We pray/keep praying, that Jesus will take care of everything." }\end{array}$

In stead of:
Waka
rerie Isa na-riwa
rerie
miolane.
1plinc-ask CONT Jesus 3sg-guard CONT complete
"We pray/keep praying, that Jesus will take care of everything."

The audience determines the origin of the sung couplets (referred to as ratnuene "they recognize") by means of these inserted words. The item isie in stead of ihie in example (6a) makes, that the song where it has been taken from is "recognized" as a Leti text. In example (8a) wuti "sash" determines the song as Tepa ${ }^{10}$ since it has /i\#/, but not /k/ (see rule 1b, 2.1 above):

$\begin{array}{lllll}\text { TAGALe } & \text { WUTI } & \text { ware } & \text { n-ala } & \text { na-rieie ... } \\ \text { when } & \text { sash } & \text { loincloth } & \text { 3sg-get } & \text { 3sg-deficient } \\ \text { tagal (Mal.) } & \text { wuti (Wet.) } & & \\ \text { "When clothing is lacking ..." } & & \end{array}$

The performer of the song where (8a) belongs to, originates from Batumiau at the Northwest coast of Leti. This line could therefore be rendered alternatively as:

$\begin{array}{lllll}\text { TAGALe } & \text { WUTU } & \text { ware } & \text { n-ala } & \text { na-rieie ... } \\ \text { when } & \text { sash } & \text { loincloth } & \text { 3sg-get } & \text { 3sg-deficient } \\ \text { tagal (Mal.) } & \text { wutu (Leti) } & & & \\ \text { "When clothing is lacking ..." } & & \end{array}$

The performer chose not to do so, because he wanted to stress the resemblance between his guest and himself, both being oraspou "boat owners" or members of immigrant clans. Had he used the Leti word he could be "recognised" as an ornusa "land owner", an aboriginal inhabitant (Van Engelenhoven 2004).

LS seldomly appears in tiatki, which are songs used in traditional lawsuits. In tiatki the text needs to be fully comprehensive to the audience. However, LS has been attested in tiatki like in (9):

$\begin{array}{lll}\text { (9a) Lanikie } & \begin{array}{l}\text { pupiniale } \\ \text { cover }\end{array} & \begin{array}{l}\text { rai } \\ \text { continent }\end{array} \\ \text { ioirie } & \begin{array}{l}\text { kadwekie } \\ \text { close }\end{array} & \begin{array}{l}\text { sletna ne } \\ \text { ocean and }\end{array}\end{array}$

"The sky covers the continents and the waves cover the ocean."

10 "Tepa" commonly refers to both Wetan and West-Babar.

11 From Indonesian tanggal "date" or Ambon Malay? 
The truth value of a tiatki depends on its relative age; the older a tiatki is, the more important it becomes. What has been applied to this particular tiatki can best be described as "literary fraud". This tiatki was used to certify the authenticity of a story about the genesis of the world. By using LS, the performer made the tiatki look older, thus more genuine than tiatki in daily speech $(9 b)$ :

\begin{tabular}{|c|c|c|}
\hline $\begin{array}{l}\text { Lanikie } \\
\text { sky }\end{array}$ & $\begin{array}{l}\text { m-pupnuale } \\
\text { 3sg-cover }\end{array}$ & $\begin{array}{l}\text { rai } \\
\text { continent }\end{array}$ \\
\hline ia:ri & n-kadwetu & sletna ne \\
\hline wave & 3sg-close & ocean and \\
\hline
\end{tabular}

\section{SPEECH BEHAVIOUR}

Singing is an apparent important feature of many cultures in the Regency of Maluku Tenggara. However, there may be considerable differences between the known wedding and farewell ceremonies in Southeast Maluku (see Geurtjens 1921; Kunst 1994) and the speech events in Southwest Maluku.

If one wants to be an orator in the latter region, knowledge of lexical parallelism (lirmarna) is essential. The principles of parallelism are semantically motivated and form part of the grammatical structure in the Luangic isolects and possibly also in the other Southwest Malukan languages (Van Engelenhoven 1997). Therefore, any speaker will be able to produce acceptable lirmarna as long as he is fluent enough in lirlèta. As such, singing is not a prerequisite for ceremonial speech. Nevertheless traditional singers are considered to be very gifted, because singing is never actually taught.

Singing takes place at major ceremonies like weddings and funerals in the entire regency. Although discourse is expectedly fixed in these contexts, it is not the text but the turn-taking strategy that is ritualized. In the Serwaru District, especially on Moa, tradition predicts that a wedding negotiation is begun by the groom's clan who sends a representative "voice" to the bride's house. This "voice" is preferably somebody of the own clan, but may well be from another clan if nobody is available. A "voice" from the bride's house, a member of the bride's clan if possible, on his turn will reply by singing from behind the closed front door. After some negotiation on the marital obligations and so on, the bride's "voice" will either invite the groom into the house ${ }^{12}$ or dismiss him. The songs that are performed during the proposing part of the wedding ceremony are subject to a principle of explicitness. They need to be as clear as possible in order not to create any ambiguity between the wedding parties. It is therefore not unusual in "inter-insular" weddings to sing partly in Malay, as with tiatki (2.2), as in (10) where the Malay words are underlined:

12 Depending on whether he is totally accepted or not, the bridegroom may enter through the front door, slip through a window, or come in via the backyard. The latter option is generally considered as very insulting. 
AONE VAN ENGELENHOVEN, Lirasniara, the sung language of Southwest Maluku151

$\begin{array}{lllll}\frac{\text { Tanama }}{\text { plant }} & \begin{array}{l}\text { bunga di } \\ \text { flower at }\end{array} & \begin{array}{l}\text { muka } \\ \text { front }\end{array} & \begin{array}{l}\text { ruma, } \\ \text { house }\end{array} & \\ \text { tiokpe } & \text { miai } & \text { wiaka } & \underline{\text { bunga }} & \text { warue. } \\ \text { so.that } & \text { I.come } & \text { I.ask } & \text { flower } & \text { two }\end{array}$

"You have planted flowers in front of your house, and I came to ask a few."

In Southwest Maluku, just as in other parts of East-Indonesia (Fox 1986), speech behaviour reflects the speaker's psyche. In these communities laughter and rapid speech are essential for a person's social acceptability. Not speaking is associated with illness, anger, or worse: (black) magic or supernatural powers. Not answering is generally considered a disgrace that must be avoided in all cases.

The crux of singing is, that it may not be interrupted. I label this phenomenon the principle of continuation. Singing is thus often the last resort to express oneself when one's speech is constantly barged in on. In this context, singing is an instrument to surpass other speech participants.

This is exemplified by a fragment from a recorded speech event in Tomra, Leti in 1990, where a man from Moa island was involved in a quarrel about his wife being unfaithful to him. During the speech event, the man did not get any opportunity to defend himself against the denigratory criticism of the other speech participants. At last the man started to sing:

(11a) Kawa rerie nara lilie iana monere+

Ririala nara lilie iana woka oiliete\#

Stop, sisters and beloved, do not go away.

Stand still, sisters and beloved, do not assemble far away.

The first line is partly in LS (underlined) as a means to stop the jeering. Further below I will elaborate on the use of LS. According to the principle of explicitness discussed above, the second line is in daily Moa, the performer's native language. In order not to violate the principle of continuation, the speech participants had to give him the opportunity to finish his song:

(11b) Ririale nara lilie+ iana woka oiliete.

Miai kiata lire molmolane\#

Stand still, sisters and beloved, do not go assemble far away.

Come and say pure words.

Now the performer has managed to break the torrent of abuse, he has the chance to defend himself properly in rapid lirmarna. After a while, some speech participants start to murmur and leave. The performer immediately continues to sing: 
(11c) Ei lire jai miolana daware winieraie+

Ririale nara lilie+ iane monere+

Ndele suke nora suke nora suke+

Mpueie iana nara lilie iana monere

Ndele suke nora+ nore wali suke\#

Hey, the pure speech and belief devastates me.

Stop sisters and beloved, do not go away.

It is because of mutual, mutual, mutual love.

Wait, don't sisters and beloved, do not go away.

It is because of love for each other.

Again LS occurs in the first line, but now it is meant to stop the people from leaving. This part is actually an apology to the listeners. The performer does not want to challenge the fact of his wife being unfaithful to him. He rather wants to hush up, because they still love each other. Next thing he does is explaining that he has a perfect marriage and that there is nothing wrong between both spouses. Anticipating on the disbelief of some of the speech participants and their intention of leaving the scene before the dispute is settled, he continues to sing:

(11d) Ririe ame+ nore ieinie likierie+

Aikia amrie iammeka ralma riore\#

$-/-$

Ralma riore+ nara lili mioie+ moie lilie+

Aikia rerie nara lilie moi lilie+

Suka nore suke lola ioirie lahe+

Suka nore nare+ suke lola ioirie\#

Stand, fathers and uncles, (you) say

We two do not behave in harmony

$-/-$

Harmony, sisters and beloved all together,

It is not always so, sisters and beloved all together.

We love each other in the open

I love (my) sister, love her in the open.

This last couplet is entirely in LS, except for half of the refrain that has been taken from the preceding (11c). The use of LS is fundamentally different from its use in the couplets above. Its function is here insisting, rather than surpassing.

As in all cultures, in Southwest Malukan contexts it may happen, that "words fail". It is here, that LS is used. LS is sung on many occasions, but is never really predictable. However, contexts where "words fail"13 appeared to be easily imaginable for everybody. The standard example of my informants was the bride's father, who at the end of the day starts to lament the loss of 
his favourite daughter while drinking himself into oblivion. In this specific case, the father sings a couplet $a d h o c$, of which the second line is repeated as a refrain by his fellow-drinkers. This type of songs is referred to in the entire region as lelana and is a kind of choral dance. Lelana are made on the spot and not normally remembered for a next occasion. A lelana is made especially in contexts of farewell. Example (12) provides a lelana which was sung when I left Leti in 1989:

\author{
Suri kiarie roma lulie monera+ \\ la mowiniota roma salona moie\# \\ $-/$ \\ roma salona moie, miorewa moie+ moie lilie \\ pela wunie niariwa moie+ moie lilie nara lilie\# \\ You leave the holy house and depart \\ to live in another pure house. \\ $-/-$ \\ Another pure house, gather thee all, beloved, \\ God shall cherish all beloved (sisters and) brothers.
}

The continuation principle prohibits the interruption of sung speech and forces singers to continue their song till it has finished. As shown above, the same principle gives people the chance to say what they want to say without being stopped by others. Being such a powerful device in discourse, singing requires the utmost of the performer's competence. Not finishing a song is regarded as extremely embarrassing, not only for the performer, but also for the audience who has to witness this failure. One strategy to prevent such kind of performing mishap is to finish the song in place of the actual performer. This is exemplified in the lelana in (12a) where the performer was overcome by sadness to such a degree, that he no longer seemed capable of finishing the song. When the performer started to hesitate (indicated in the text by four dots ...), somebody in the audience stood up and finished the song in his place. Because he did not know the actual text, the second performer made the best of it by creating an entire new couplet that matched the earlier performed text. The second text (12b) is actually a song of a different type, called sniaruanna "Banda-song":

\title{
Lerulie liwi liaie liopa-lopienie+
}

Iaruse ianinie keni nialora\#

$-/-$

Keni nialora+ nara makui-kui wurie+

Lilie nara makui wur...

(lelana)

In olden days the reef and the cliffs were where Dolphins took off on the waves.

$-/-$ 
Took off, sisters, make up your mind

Beloved sisters, make up your ...

(12b) Wunie kawera lime+

Ri nora ialie.

(sniaruanna)

Wunie niawera reri aisise+

Mana namori lina+ raiamane\#

God separates ${ }^{14}$

Man from his brother.

God separates me forever

Because She gives birth to the generations on the Earth. ${ }^{15}$

The contexts "where words fail" form the domain for LS. Beside lelana, the singer in the Serwaru and Tepa Districts has at least two other types of song at his disposal: the sniaruanna or "Banda-song" introduced above and the sniarmòa or "Moa-song". A lelana requires active participation of the audience who has to repeat the refrain. The audience merely listens to the latter two. I have not yet been able to grasp the precise difference between a "Bandasong" and a "Moa-song", except for their different melodies. However, as far as I know now "Moa-songs" do not evoke any reaction from the audience, whereas "Banda-songs" are always reacted upon. ${ }^{16}$

Song types that were mentioned to me, but which I have never heard on Leti are the "Tepa-song" and the "Kisar-song". The latter type was sung to me once on Seram by a Leti informant in 1980. His songs, however, appeared to be in Meher and Oirata and not in LS. During a fieldwork session in the Netherlands in 1984, a Meher informant produced some songs that matched the LS lexicon, and at the same time fitted in the LS domain. An example is given in (13).
Pudi ka walola $+\underline{\text { ka walola }}$
oirie mahi reie [rehie] alahe meluie [maloie].
Sentiment does not go across
Dominant salt water and far forests.

This song (among others) was immediately identified by Leti speakers as a "Kisar-song" due to its melody. The words oirie "water" and ka "no" were recognized as Meher. ${ }^{17}$

see 2.2.

Here the verb does not agree with its subject, because it is actually inflected for $1 \mathrm{pl}$,

15 Literally: "Father of Continents".

16 Another difference is the length of the texts. "Banda-songs" have an additional third line, whereas "Moa-songs" and the "Kisar-songs" discussed further on have only two lines.

17 Surprisingly nobody suggested to change them respectively in ioirie and aitia, in order to get "good LS". 


\section{EXTERNAL SETTING}

The social unit in the region is the clan. The status of the clan may differ per island ${ }^{18}$ and is a decisive element in clan discourse, whether it is traditional (for example marriage petitions) or not. As such, it is continuously reassessed. Tradition distinguishes two groups: aboriginal inhabitants, referred to as land owners ${ }^{19}$, and immigrants, referred to as boat owners ${ }^{20}$. Whereas land owner clans are confined to particular islands, boat owner clans that share the same name are found on various islands. The latter maintain many alliances across islands whose origins are found in the respective myths.

The island communities of Southwest Maluku maintain an economic network, called Nuspaikra-Rapiatatra "the Guided Islands and Ordered Continents", where inter-insular trade has been defined (Van Engelenhoven 2004). Each island has its own export product. Leti, for example, exports arka, a kind of gin distilled out of the juice of the Borassus sundaicus tree. Tradition dictates, that none of the islands belonging to the network may barter arka to Leti. Similarly, Moa may barter large seafish to Kisar, but not to Luang whose export product is seafish. This economic co-operation is just one manifestation of the cultural exchange that takes place between these islands.

After the incorporation of East-Timor into the Indonesian state auriferous formations were discovered in the mountains on Wetar island. The Authorities granted the concession rights to an Australian mining company and started to open up Southwest Maluku by improving its infrastructure. Since then the region is becoming more and more involved in the economic development of the Maluku Tenggara Regency.

Steamships from Ambon travel to the south via two routes. On the "long route" the ship runs from Ambon eastward to Kei (Tual) and Aru (Dobo). Here it turns to the west and continues his trip to Kisar in the west by passing the Tanimbar and Babar archipelago. At Kisar it takes the same route back. The ships that take the "short route" go from Ambon to Damar where they head for Tual, passing all the Southwest Malukan and Tanimbar islands. In Tual they return the same way. This means that all the islands on the routes are frequented about four times a month. Additionally, there is a line between Kupang and Kisar. Large passenger ships travelling up and down from Surabaya (East-Java) to Sorong (Bird's Head) call in at Kisar and Moa. Ever since the Summer Institute of Linguistics included Southwest Maluku into its research program, Moa and Kisar may now also be reached by aeroplane and an airport is being built on the latter island. A network of radiotelephone units (Radio Telekomunikasi Daerah, RATELDA) supports wireless communication between the main islands of the districts. Southwest Maluku lacks telephone connections. However, a telegraph station is found in Wonreli.

18 The Analiona clan for example is of importance in Klis (East-Moa, De Josselin de Jong [ND]), but has a subordinate position in Batu Merah (West-Damar, Pannell 1991).

19 Ornusa in Leti and tuan tanah in local Malay.

20. Oraspou in Leti. 
All villages have been provided with at least one primary school where Indonesian is not only the language of instruction, but also the only vernacular allowed. Secondary schools are found in the administrative centre of each district. For higher education one either has to go to the regency's capital Tual in the Kei archipelago, or to the provincial capital Ambon. The goal of the indigenous language ban in school, as I was informed, was to force the children to improve their skills in the Indonesian language in order not only to achieve better access into the world of education and technology, but also to be more capable of expressing one's thoughts.

A noticeable side-effect of all these attempts to implement the modernization process in Indonesia into the region and to accustom its population to it, is a allegiance shift among younger generations towards local Malay and standard Indonesian. The local variant of Malay, called Melayu Tenggara Jauh "Far Southeast Malay", is used in ordinary speech, whereas standard Indonesian is confined to writing purposes and the pulpit. The musical preference of the population mainly concentrates on religious hymns in Indonesian and kroncong in Ambonese Malay, popularly referred to as radio Ambon. Youngsters, who can afford a radio, also fancy Australian pop music, which they call radio Darwin.

Southwest Maluku is generally considered by its inhabitants as a lagging region where one cannot profit from the economic progress that the Indonesian state, and thus the Malukan province, are experiencing at the moment. Especially the Serwaru district features an exodus of young people in search of a better future. A recurrent characteristic in this district is, that the emigrants abandon their mother tongue in exchange for the language that is spoken in their new homestead..$^{21}$ This is not only very salient in Tutukei (Leti), where only a minority of older people may still speak the indigenous dialect. It is an eminent feature of the Southwest Malukans living in the Netherlands who have either shifted completely to Dutch or to Ambonese Malay, depending on their respective military backgrounds. ${ }^{22}$

\section{DISCUSSION}

Singing evidently belongs to the cultural heritage of the entire Maluku Tenggara Regency. The language used for singing will mostly be a ritualized variant of normal speech, and as such these songs will be used for the own speech community and will not be intelligible for outsiders. Lirasniara is different in that it is used over a vast area by different speech communities, even the non-Austronesian Oirata on Kisar. In De Josselin de Jong's (1937) analysis of an Oirata clan myth seven of the ten songs are clearly not Oirata but Luangic-

21 An interesting phenomenon is the emerge of a vernacular based on the Leti variant as spoken in Tomra. This vernacular is spoken by youngsters in Paso and Batu Gantung (Ambon). A more simplified variant occurs in and Jakarta where it is spoken by the middle aged and older generations.

22 Part of the Southwest Malukans who came to the Netherlands followed the Ambonese soldiers of the Royal Dutch-Indies Army (KNIL) in 1952. The other part came individually with the Royal Navy during the Indonesian struggle for independence. 
Kisaric. Although the text was obscure for the narrators themselves (De Josselin de Jong 1937: 79), it was fully intelligible for a LS expert from Leti.

What was this Lirasniara? According to oral traditions, LS once functioned as an intermediate vernacular between the islands of Nuspaikra-Rapiatra. What did it look like and how did it function? The loss of PAN *q without the emerge of long vowels as in the case of Leti (Van Engelenhoven 1995) is easily explained in a sung scenario. Glottal stop insertion and vowel length loose their distinctiveness, and thus their phonemic status, in songs where they are respectively linked to interludes in and continuation of the melody. The fact, that LS is only sung is by itself a highly suspect feature that actually makes it inappropriate for normal discourse. If LS has been a contact language as tradition wants it to, then it was probably not sung initially.

Recall, that the Austronesian isolects in the Nuspaikra-Rapiatatra region all descended from the same proto language, which is clearly visible in the similarity of their respective syntactic patterns. From the lexicostatistical point of view the margin of lexical differentiation is $55 \%$ at the most (Taber 1993). Before Malay was introduced koineization may have been a reasonable option for the creation of a comprehensible contact language. Siegel (1985:373) applies the term "stabilized koine", when "[...] lexical, phonological, and morphological norms have been distilled from the various subsystems in contact, and a new compromise subsystem has emerged. The result [...] is often reduced in morphological complexity compared to the contributing subsystems". On the one hand do the collapse of the singular-plural distinction in second person inflection, the raise of * $u$ \# to $i \#$ and the salient palatalization of immediately subsequent consonants suggest, that LS was a result of a koineization process of Luang and Eastern Luangic isolects (Luang or Wetan-Tepa).

The sound changes on the other hand made LS rather unsuitable for contact purposes because of the inherent ambiguity attached to the high amount of homonyms in its lexicon. The tendency of singers to insert new items from either Malay or their own mother tongue is easily explained as a means to meet this ambiguity. Nothing can be said about the chronology of the sound changes discussed in 2.1. However, if the merger of PLK *t and *k into LS k, which caused much homonymy, was relatively early, then the insertion of lexical items may well be intrinsic to LS. In this scenario LS would be a jargon rather than a koine. According to Mühlhäusler (1986: 135-136) jargons "[...] are individual solutions to the problem of cross-linguistic communication and hence subject to individual strategies, the principal ones being lexicalization or holophrastic talking; pragmatic structuring [context-dependency]; grammaticalization by transfer; and universals". From this point of view the obsolete person inflection in LS could be explained as a characteristic of jargons. Its limited lexicon and the subsequent insertion of "alien" lexical items are then manifestations of the illusion of double communication: "[...] the contact jargon is systematically relatable to both parties' native languages, and is perceived as a kind of lexical extension of some variant of the native 
grammatical system" (Silverstein 1972). ${ }^{23}$

Whatever character LS may have had initially, Malay, the trade language par excellence, must have taken over its function as a contact language as soon as it was introduced in the region. In the first millennium BC Maluku already formed a part of a large trade network (De Jonge and Van Dijk 1995: 20). The earliest seventeenth century contacts between Western traders (Javanese and European) and Southeast Maluku islanders was indirectly via the Banda islands where sago and gold from Kei and feathers from Aru were bartered for textiles (Meilink-Roelofsz 1962: 95). Southwest Maluku, however, was either not or only indirectly involved via sailing ships from Teun, Nila, and Serua that brought products to trade posts on Timor and Banda. This fact may explain the back-formation of certain Malay loans in Leti like -sòrmata "to greet" (< hòrmata < hormat).

Malay was introduced together with the Christian religion in the nineteenth century. The Christianization campaign of both the Ambon and Timor Societies of the Dutch Reformed Mission was severely hampered by the fact, that the population did not yet speak any Malay while the missionaries did not speak any indigenous language (Neurdenberg 1876). This fact directly underlay Reverent Heijmering's (1846) preliminary study of Leti grammar. If Malay was not yet used by then, it is very well possible that LS was still functioning as contact language in the nineteenth century.

Language shift is a very common phenomenon in Southeast-Maluku. People easily swap when a language no longer is satisfactory. Malay was a far more suitable candidate for a contact vernacular than LS ever was. It already functioned as a lingua franca in Insular Southeast-Asia since the seventh century AD (Steinhauer 1980: 350). It is therefore no surprise, that, after its introduction into Southwest-Maluku, it took over the intermediary role of the inferior LS.

I hypothesize, that the singing of LS became fashionable at the time, that LS was still prevailing. A comparable phenomenon occurred in the Netherlands during the late fifties and early sixties when British pop groups like the Beatles and the Rolling Stones contributed heavily to the popularization of English as the vernacular for singing. In spite of the recent counteraction to promote the use of Dutch or even its dialects, the position of English is still unchallenged. As such LS is a perfect example of the "latinate pattern" of language death where "the language is lost first in contexts of family intimacy and hangs on only in elevated ritual contexts" (Hill 1980). ${ }^{24}$ However, being a jargon, it is highly improbable that LS had any first language speakers. ${ }^{25}$

23 Quoted in Romaine (1988: 120). Another manifestation of the illusion of double communication that I experienced myself occurred during a radio show for the NCRV on 2 August 1996, when a Keiese interviewee whom I was singing to, assured that he had understood me, even though he did not know the words.

24 Quoted in Campbell and Muntzel (1989: 185).

25 Another comparison with Dutch pop music seems in order here. In the sixties the Belgian singer Jacques Brel popularised one specific kind of song, the chanson, which must be sung in French. In Southwest Maluku at least one correlate of the chanson can be found: the 
Recall, that the two Meher informants I consulted in 1980 and 1984 provided texts in three different languages, Oirata, Meher and LS. The use of Oirata, however, is subject to the severe social constraints on Kisar, which separate both speech communities. Meher people are not expected, to put it mildly, to speak any Oirata and Oirata people are not expected to speak their own language outside their territory. This did not apply to the 1980 informant who was an outsider of Leti origin. He therefore could sing in both Oirata and Meher. The 1984 informant sang in LS, not in Meher. This fact, as I learned later, was linked to the Luang origin of his clan house. Differently stated: the performer performed in LS, to stress, that both his and the investigator's clan house, albeit located on different islands, originated from Luang. A similar motive made one of my Leti informants (see 2.3) decide not to add Leti lexical items in his song. In this case, the performer wanted to signal the mutual relation of the singer and the investigator as "boat owners".

Here LS is used as an instrument for social identification. An extra dimension in the relation of this specific Meher informant and the investigator was, that their respective clan myths coincide in one historical event. According to other Meher informants, these songs were a peculiarity of the performer's clan that were not representative for Meher society. This remark suggests, that for him, LS functioned as an argot, "a specialised vocabulary used by a distinct segment of society" (Grimes and Maryott 1994: 309). The speech behaviour of the Leti singer shows, that in his speech community LS is a speech style or register rather than a separate argot. This is once more confirmed by the speech behaviour of the Moa singer (see 2.3), who inserted LS in his sung speech to overrule his speech participants.

\section{CONCLUSION}

Lirasniara once was a jargon used between the islands of the Nuspaikra-Rapiatatra network. After its introduction into the area, Lirasniara quickly lost ground to the structurally stable Malay. The fact, that Lirasniara already occurred in sung texts by then prevented a rapid disappearance through oblivion. The jargon could therefore evolve into an argot in the Meher language, while it was reduced to a highly marked speech style in the Luangic dialects.

Lirasniara owed its survival thus far to the isolation of Southwest Maluku. Now that the region is more and more included in the modernization process of Indonesia, Lirasniara looses its last, marginal function of stylistic embellishment to new ideas and trends that permeate and transform the traditional cultural framework.

It is necessary not only for science, but also for the islanders themselves, that their songs be collected and studied before it is too late. The knowledge of the songs is indispensable for the narration and interpretation of the mythical stories that are also under high pressure in this region. And, to quote the American Indian author Leslie Silko, "When there are no stories, there is nothing".

Liruanna or the Banda song, which is entirely sung in LS. 


\section{LIST OF ABBREVIATIONS}

CONT : Continuative

Jer. : Jerusu

LS : Lirasniara

Mal. : Malay

Meh. : Meher

pl : plural

PLK : Proto Luangic-Kisaric

sg : singular

SV : Subject-Verb

$\mathrm{V}$ : Verb

VET : vetative

Wet. : Wetan

\section{REFERENCES}

Campbell, Lyle and Martha C. Muntzel. 1989. "The structural consequences of language death", in: Nancy C. Dorian (ed.), Investigating obsolescence; Studies in language contact and death, pp. 181-196. Cambridge: Cambridge University Press. [Studies in the Social and Cultural Foundations of Language 7.]

Engelenhoven, Aone van. 1995. "Van Proto Malayo-Polynesisch naar Proto Luangisch-Kisarisch", in: Connie Baak, Mary Bakker, and Dick van der Meij (eds), Tales from a concave world: liber amicorum Bert Voorhoeve, pp. 246264. Leiden: Projects Division, Department of Languages and Cultures of Southeast Asia and Oceania, Leiden University.

Engelenhoven, Aone van. 1997. "Words and expressions; Notes on parallelism in Leti", Cakalele Maluku Research Journal 8: 1-25.

Engelenhoven, Aone van. 2004. Leti; A language of Southwest Maluku. Leiden: KITLV Press. [Verhandelingan 211.]

Fox, James J. 1986. “Leluhur kami berbicara dengan kata-kata berpasangan: pandangan orang Roti tentang bahasa, dialek, dan tata cara", in: James J. Fox (ed.), Bahasa, sastra dan sejarah; Kumpulan karangan mengenai masyarakat pulau Roti, pp. 144-199. Jakarta: Djambatan [Seri ILDEP.]

Geurtjens, H. 1921. Spraakleer der Keieesche taal. Weltevreden: Albrecht, 's-Hage: Nijhoff. [Verhandelingen van het Bataviaasch Genootschap van Kunsten en Wetenschappen 63.]

Grimes, Charles E. and Kenneth R. Maryott. 1994. Named speech registers in Austronesian languages, in: Tom Dutton and Darrell T. Tryon (eds), Language contact and change in the Austronesian world, pp. 275-319, Berlin: Mouton de Gruyter. [Trends in Linguistics, Studies and Monographs 77.]

Heijmering, Geerlof. 1846. "Bijdrage tot de kennis van de taal der Z.W. eilanden, benevens een proeve van vergelijking met acht andere inlandsche talen", Tijdschrift voor Indische Taal-, Land-en Volkenkunde 8(3): 1-81. 
AONE VAN ENGELENHOVEN, Lirasniara, the sung language of Southwest Maluku161

Hill, Deborah. 1980. "Language death in Uto-Aztecan". Paper for the Conference on Uto-Aztecan Linguistics, Alberquerque.

Jonge, Nico de and Toos van Dijk. 1995. Vergeten eilanden; Kunst en cultuur van de Zuidoost-Molukken. Amsterdam: Periplus.

Josselin de Jong, J.P.B. de. 1937. Studies in Indonesian culture; I. Oirata, a Timorese settlement on Kisar. Amsterdam: Noord-Hollandsche UitgeversMaatschappij.

Kunst, Jaap. 1994. "Music and dance in the Outer Provinces", in: Jaap Kunst, Indonesian music and dance: traditional music and its interaction with the West, pp. 173-204. Amsterdam: Royal Tropical Institute, University of Amsterdam, Ethnomusicology Centre 'Jaap Kunst'.

Meilink-Roelofsz, Marie A. P. 1962. Asian trade and European influence in the Indonesian Archipelago between 1500 and about 1630. PhD Thesis, University of Amsterdam.

Mühlhäusler, Peter. 1986. Pidgin and Creole linguistics. Oxford: Basil Blackwell. [Language in Society 11.]

Neurdenberg, J.C. 1876. "Hoe de zending de Zuidwester-eilanden tot zegen had kunnen worden; Nog altijd een les voor de toekomst", Mededeelingen vanwege het Nederlandsch Zendelingengenootschap 20: 247-257.

Pannell, Sandra N. 1991. Narrative boundaries, national horizons: the politics of identity in Amaya, Maluku Tenggara, Indonesia. PhD thesis, University of Aidelaide.

Romaine, Suzanne. 1988. Pidgin and Creole languages. London: Longman.

Sasse, Hans-Jürgen. 1992. "Theory of language death", in: Matthias Brenzinger (ed.), Language death, factual and theoretical explorations with special reference to East Africa, pp. 7-30. Berlin: Mouton de Gruyter. [Contributions to the Sociology of Language 64.]

Siegel, Jeff. 1985. "Koines and koineization", Language in Society 14: 357-379.

Silverstein, M. 1972. “Goodbye Columbus; Language and speech community in Indian-European contact stiuations". Manuscript.

Steinhauer, Hein. 1980. "On the history of Indonesian", Studies in Slavic and General Linguistics 1: 349-375.

Taber, Mark. 1993. "Towards a better understanding of the indigenous languages of Southwestern Maluku", Oceanic Linguistics 32: 389-441. 